\title{
Social Order, Regimes of Truth and Symbolic Disputes: A Framework to Analyse Educational Policies ${ }^{1}$
}

\author{
HÉCTOR MONARCA, ÁNGEL MÉNDEZ-NÚÑEZ \\ Department of Pedagogy, Faculty of Teacher Training and Education, Autonomous University of Madrid, Madrid, 28049, Spain \\ Email: hector.monarca@uam.es; angel.mendezn@uam.es
}

\section{NOELIA FERNÁNDEZ GONZÁLEZ}

Department of History of Education and Comparative Education, National Distance Education University (UNED), Madrid, 28040, Spain Email:nfernandez@edu.uned.es

\begin{abstract}
This article offers an epistemological framework to analyse how hegemony is constructed in the field of education, as part of current debates in the social sciences on the aperture and closure of the social. Our central thesis is that, beyond the post-structuralist tendency that dominates these debates, we must reconsider the potential effects of its theoretical assumptions on the social world, i.e. not only on its representation, but also on its structures, subjects, objects, and phenomena in general. To that end, we will analyse by the way of example the discourses on quality of education, core in education policies since 1980s, from this epistemological framework. Moreover, this type of discourses also allowed the instituted powers to connect the traditional forms of production and reproduction of 'the social' to new forms that help consolidate its hegemony by improving the efficiency and effectiveness of the ways to produce and accumulate capital, and thus legitimize them. Indeed, as a framework, quality had and still has a totalizing effect on the hegemonic re-adjustment and re-working of capitalism that began in the late 1970 s.
\end{abstract}

Keywords: social science, political theory, social order, regimes of truth, symbolic disputes, educational policies

\section{INTRODUCTION}

Since Gramsci and his conceptualization of hegemony, the idea of 'the social' as an articulation of positions has taken an increasingly prominent place in the approach to studies of social and

1 This article has been prepared in the frame of the Research-Review Project 'Profesionalización Docente: Discursos, políticas y prácticas. Nuevos enfoques y propuestas' which has been submitted under the 2020 call for R\&D\&I projects of the Spanish Ministry of Science and Innovation 'Programa Estatal de Generación de Conocimiento y Fortalecimiento Científico y Tecnológico del Sistema de I+D+i, del Plan Estatal de Investigación Científica y Técnica y de Innovación 2017-2020'. 
political science (Laclau, Mouffe 1985). Stepping back from the Marxist perspective, they arrive at a romantic 'conception of hegemony according to which the forces interested in putting an end to exploitation and those more determined to perpetuate it would coexist peacefully, in pluralism and democracy, revolution and counterrevolution' (Borón, Cuéllar 1983: 1144). Interestingly, in this framework, post-structuralism has been interpretively accompanying the deconstruction of the social to the point of having dismantled the 'social order' as a relevant analytical category. While its discredit was gaining followers, 'the instituted' was analytically diluted until it became practically invisible. We thus reach a paradoxical point where overconfidence in the aperture of the social, its romantization, its essentialization, may be acting in a sense of closure, inasmuch as, having contributed to the invisibilization of the instituted - of 'the political' in Castoriadis's terms (1997) - it hinders 'politics', understood as the dispute over the instituted.

In this sense, discourses about quality of education are here analysed as a framework for the production and reproduction of hegemony. These discourses assemble an authorized framework for discussion and disputes, articulating categories, principles, ideas about what is good education, what is desirable and expectable. In this vein, quality, as a substitute for education, has for several decades been shaping the permitted, visible space of discussion, of dispute, of possible articulations-condensations. Thus, it is not that we reject the post-structuralist premise about the existence of totalizing ${ }^{2}$ articulatory processes (Laclau, Mouffe 1985); rather, we question the faith deposited in the aperture of these articulatory processes and any vision that presents them as an invitation to coordinate positions amicably to build a better world together. Likewise, we consider it necessary to pay attention to the potential invisibilizing effects that post-structuralist discourses can have on power and on what has already been instituted in articulatory processes. Even though the post-structuralist view does not deny power, we find that it waters it down or blurs it by making it 'like a mesh of relations that crisscrosses society as a whole' (Castro-Gómez 2015: 41). Our thesis is that, when power is understood in these terms, it ends up generating an idea of distribution, even equitable distribution, that in fact only limits the strength of the critique as well as its dispute. Finally, following this line, by highlighting the supposed aperture of the totalizing articulatory processes, it ignores the totalizing already instituted as a sociohistorical process, the instituted of the social. Even from post-structuralist perspective, we could admit that the positions the differences - are articulated with each other, if it happens, in contexts that are always already in some way articulated with more or less aperture or closure. As Martinez (2007: 137) explains in his work on Bourdieu, 'permanent frameworks of mental life had to be constituted in order to be able to be constituent, had to be given a shape in order to be able to shape, had to be structured in order to become structuring. Indeed, if aperture even exists, it does not come about as an essential feature of the social order, but rather of the dispute and struggle of subjects who resist closure, which, in turn, in an inexhaustible exercise of its power, resists ceasing to be so. As Kohan (2013: 34) suggests, the dominant post-structuralist tendency does nothing but grant 'ontological rank to what is nothing more than a historically determined moment of capitalism'.

2 Laclau and Mouffe (1985: 105) call articulation 'any practice establishing a relation among elements such that their identity is modified as a result of the articulatory practice. The structured totality resulting from the articulatory practice, we will call discourse'. 
The quality dispositif is taken here as a social order, a regime of truth, and a symbolic dispute. Moreover, this approach joins a critical analytical tradition that explores the organizational meanings-categories of a social order that articulates, sustains and underlies a dispositif that produces and reproduces principles of thought, perception and action (Bourdieu 1988) and invisibilizing processes of other assumptions or principles of the representation of the world that remain unthought of, especially regarding the articulations-condensations that it suggests or establishes among education, schooling, socialization and social order. Accordingly, the article is intended as an exercise in 'suspicion', 'questioning' and 'critique'; it aims to draw attention to the construction of categories that 'dispute' how to understand the world (i.e. the social order), the education, and its relations. It thus seeks to highlight the systems of order, appropriation and exclusion that govern the social order in an exercise of critique and resistance (Popkewitz 1994).

\section{AN EPISTEMOLOGICAL FRAMEWORK: SOCIAL ORDER, REGIMES OF TRUTH AND SYMBOLIC DISPUTES}

Given the above-mentioned assumptions, this paper analyses the quality of education as a regulator of processes geared to constructing hegemony in the framework of the production and reproduction of the social order. Accordingly, it starts from three key ideas that support the argument: social order, regimes of truth and symbolic disputes.

The first of these ideas, social order, refers to fields and practices that have been shaped historically and are now institutionalized. In consonance with Bourdieu (1989: 14), and in contrast to the post-structuralist conception, 'there exist, within the social world itself and not only within symbolic systems (language, myths, etc.), objective structures independent of the consciousness and will of agents, which are capable of guiding and constraining their practices or their representations. As this proposal has it, to properly conceptualize the social order, one must pay attention to the role of the nation-state as a political system and its peculiar relationship with the capitalist system; in addition to this, other keys to understanding social order are patriarchy (Federici 2004) and colonialism (Amin 1990; Quijano 2000). Thus, social order refers to the instituted, to institutionalized and consolidated power, to the system of unequal distribution of wealth and, therefore, of opportunities. In short, it refers to the system of production and reproduction aimed accumulation (Marx 1990; Wallerstein 1983).

On the other hand, regime of truth refers to the rationality that upholds the social order. Articulation-condensation state-capitalism-patriarchy-colonialism (Fraser, Jaeggi 2018) would configure the invisibilized regime of truth that upholds modernity. As for being made invisible, first and foremost, the regime of truth corresponds to the closed part of the social, the undiscussed. Both social order and regimes of truth are partly related to Bourdieu's concepts of field and habitus (2014). At the same time, the idea of a regime of truth also refers to the social order internalized by subjects in their own process of socialization, of subjectivation. The 'regime of truth' establishes or sets a gnoseological order: the immediate meaning of the world (Bourdieu 1989).

In a structuring process of totalizing articulations, the 'regime of truth' is the structured socio-historical background, like fields and habitus, initially closed insofar as it is instituted. In this case, quality as a framework that supposedly opens up to articulation is already loaded with instituted meanings. The regime of truth underlies the articulatory framework, sustains 
the dispositif, in this case quality, but at the same time it is produced-reproduced in this framework-dispositif. Two features thus appear, like tensions: one of its continuity-perpetuation, the other that of its possible re-updating. The regime of truth is the context of possibility of certain predispositions-orientations. At the same time, it is created, sustained and reproduced by them in the complex interactions within the field that it articulates-condenses. In this regime of truth, power-knowledge (Lander 2000; Quijano 2000) appears by promoting and pretending - subjecting - a subjection of public action, of politics, to a particular social order; a subjection of education-schooling to this social order. The regime of truth is the social order built into culture, institutions, the subject, the field, the habitus - it is all of this; embodied, internalized-subjectified, objectified in various cultural-social products-practices. As a symbolic system, the regime of truth is a regulator of the allowable, the desirable and the unspeakable in discourses, policies and practices.

Finally, the concept of symbolic disputes (Monarca 2018) seeks to address precisely the aperture of the social system. However, unlike post-structuralist approaches, which in our opinion end up essentializing aperture (Borón 2000), it is presented here as a possibility of 'assaulting' the instituted. Aperture would thus not be an ab aeterno feature of the social: it would not be the instituted-structured tending toward instituting-structuring that would simply open up as an essential tendency, but rather, it would result in and from the collective struggle, from antagonisms, conflicts, opposition, resistance to the instituted order. Aperture is a possibility, not a metaphysical-ontological essence (Kohan 2013), and should always be disputed as political subjects. It refers to 'politics', the breakdown of 'the political', the dispute for the order, for truth as power-knowledge.

\section{QUALITY OF EDUCATION AS A POWER-KNOWLEDGE DISPOSITIF}

In this framework, quality is, of course, much more than a phenomenon that can be 'trapped' in a simple concept with a degree of margin for dispute over its meaning. Rather, it is configured as a dispositif from a regime of truth that condenses a wide variety of elements from the educational field and other fields and from the social order in general, bolstering the gears of its reproduction. That is in fact why we understand that the dispositif of 'quality', beyond its relative and apparent aperture as an empty signifier (Laclau, Mouffe 1985), is already installed with the logic of a master-signifier. It is a way of making us talk, discuss and think about education 'which in itself contains rules and categories that delimit the debate and that act as regulators of the social world' (Monarca 2018: 5), with a clear effect of closure. Here the important thing is that quality, before opening up to the game of totalizing articulation - of the dispute for hegemony - of which Laclau and Mouffe (1985) speak, already closes a field loaded with predefined closed meanings, many of which emigrated from other fields (Bourdieu 1989). Much as we have defined 'symbolic dispute' in this article, strategically disputing the signifier 'quality of education' in order to substitute its current neoliberal meaning with an alternative one is an insufficient option to break with the established social order, since, as we have said, 'quality of education' already functions as a framework, inserting and at the same time invisiblizing meanings and orientations about education.

This quality mechanism has kept the debate on education - its institutionalization and the configuration of teaching - to the transformations underway in the framework of the broader processes of state reform taken on as of the late 1970s under the auspices of neoliberalism, as an reassertion of capitalism. 
In this sense, having invizibilized the link with the political and keeping it safe from harm, the dispositif opens up an alleged space of dispute that, only as a Lacanian fantasy, works as politics, but in reality is a mere connection of policies, understood as technical actions, to a set of principles and structured orientations structuring the social order, through a set of elements that we assume as part of the dispositif: oral and written discourses, rules, documents, practices, artifacts, etc.

We can place the beginning of the quality dispositif as a form of government of education in a context in which the functioning of the welfare state is questioned from a neoliberal, economics-based rationality strongly focused on cutting back social spending (education, health, etc.), i.e. as a way of maintaining and reasserting capitalism. Here quality, and its continuous and endless improvement, was associated with privatization (Moschetti, Verger 2020), school autonomy (Holloway, Keddie 2019), parental school choice (Gabay-Egozi 2016), accountability and results-based management (Clarke 2014); upheld by neoliberal assumptions, such proposals would either result in the desired quality or become transformed into features that define it. Thus, privatization, accountability, autonomy, school choice and other more recent strategies such as school specialization, including bilingualism in Spain, are in some way part of the quality dispositif as a regulatory framework loaded with categories that guide and prescribe. In the field of education, this type of quality dispositif helps condense, give coherence and articulate new concepts, new meanings and new practices that arise as a new banner of what is desired, expected, the good that is projected as the new professional common sense of education.

In this context, quality as a dispositif is transformed into an allegedly new story meant to give coherence and meaning - new meanings - to a wide variety of education-related aspects (Fernández-González, Monarca 2019; Ozga 2008). The alleged novelty helps invisibilize its link with the social order and to disarticulate or dissociate the pre-existing powerful theoretical criticism of this social order. In this sense, the quality dispositif performs the role of regulator-articulator in the processes of political reform in education, and connects the principles of neoliberalism with the common sense of liberal and capitalist modernity already established and assumed as an undisputed ideology. Thus, it acts by connecting the regimes of truth of our social world regarding capitalism, patriarchy and colonialism.

From this perspective, this dispositif has a colonizing effect on education that contributes to installing, propagating, consolidating, closing and legitimizing this symbolic-gnoseological order (Bourdieu 2014). As a symbolic system, it helps define 'acceptability', 'what is desired', 'right', 'good', 'unspeakable, 'the unnamable,' 'the rules of saying, thinking and doing' (Bourdieu 2014; Popkewitz 1994). It also uses its alleged novelty to connect and reasserts the naturalist and positivist paradigm and instrumental rationality with educational discourses, policies and practices (Monarca 2018). From these apparently neutral references, quality becomes a category that mirrors agreements or disputes otherwise hidden in simple, superficial and interested discourse, a type of 'expert', technocratic discourse full of rhetoric but empty of any contextual, socio-historical content. Appealing to common sense - to the supposed natural-objective order of things, thanks to its reification processes, such discourse builds a direct link, a 'synonymization, between quality education and good education, establishing a relationship that produces and reproduces new power relations that regulate education and teaching.

From this perspective, the quality dispositif is a powerful condenser of disputes regarding the meanings and direction that education reforms should take, in complicity with academic output regarding the movement for effective schools, school improvement, and, in 
general terms, the process-product approach, where it found a firm legitimizing foundation. Within this framework-logic, the idea of reform takes hold as a constant need for change, supposing it to be a continuous movement towards improvement (Popkewitz 1994).

Framed in capitalism, under neoliberal rationality, and backed by the above-mentioned academic movements, the quality dispositif uses its regulatory framework to equate political reform with change-improvement-innovation. Thus, the regime of truth that sustains the dispositif performs two important operations. First, it dilutes the concept of reform in the concepts of change-improvement-innovation, distancing it from the deeper connotations of reform. As a result, rather than entailing a more profound political discussion, it subjects it to an exclusively technical idea (Popkewitz 1994). Second, it instills the idea-need of permanent movement and change on the basis of the established rationality. To this, evaluation is joined in a peculiar way, in an inexhaustible circle that requires a continuous scrutiny that controls and subjects the action geared towards an unreachable 'desired object', a fantasy or a lack in the Lacanian sense (Žižek 1989).

This turns quality into something that must always be sought. And added to this is a pretension of novelty that silences, invisibilizes and forgets the systematically rigorous criticisms previously made of capitalism-schooling in the decades leading up to its emergence as a dispositif. And this brings about another, clearly ideological effect, because as Žižek (1989: 49) states, we no longer feel 'any opposition between it and reality' as it has reached to determine 'the mode of our everyday experience of reality itself'. Quality as a regulatory framework is, in the 'apparent debate on education', 'the place where the fate of our internal, most "sincere" and "intimate" beliefs is in advance staged and decided' (Žižek 1989: 42). Thus, the regime of truth underpinning the quality dispositif hints at something post-structuralist discourses ignore, namely, that which does not appear visibly articulated in any evident way, even if it is part of this supposed articulation.

\section{FINAL REFLECTIONS}

As a regulating dispositif, quality acts as a 'supreme principle' that makes up for the lack - in the Lacanian sense - and redeems us from sin, that which is normalized, naturalized, something we must fight or strive for, knowing that it will always be ahead of us - beyond the here and now in which we find ourselves; forever pushing us towards a non-present moment, unconnected to the past and articulated with a single possible future-horizon (Clarke 2014). This is what requires and justifies our vigilance, scrutiny and continuous assessment to order-discipline our behaviour-practices towards it, making us acknowledge our sins and confess them. The quality dispositif operates by technifying discussions, depoliticizing them, and transforming education into a technical and managerial problem (Bourdieu 2014; Clarke 2014; Popkewitz 1994).

In this way, the quality dispositif articulates us - anchors us - with a regime of truth given by the same order of things that is configured in the field it defines, thereby exercising a powerful form of persuasion (Bourdieu 1989). It demarcates and closes an order; it defines the grammar of educational discourses, policies and practices; an order that includes 'the categories of perception, the systems of classification, that is to say, essentially, the words, the names that construct social reality' (Bourdieu 1988: 137). Accordingly, we can think of the quality dispositif as a territory where disputes over classifications, divisions and hierarchies of the social world - for guiding, imposing and/or manipulating the objectified structure of society' (Bourdieu 1988: 141) - are technified and disciplined, removing them from any real dispute for the social order - the already totalized articulations. 
In other words, quality is configured as a regulatory field, as a symbolic and technical system defined in the network of meanings, signifiers, practices and other elements that appear articulated and articulating to give meaning to the field of education (Fernández-González, Monarca 2019). In that way, it is a reserve for producing or reproducing certain senses of the social world and education: a framework for imposing 'political classification systems under the legitimate guise of philosophical, religious, legal, etc., taxonomies' (Bourdieu 2014: 71), scientific, technical.

In this line, the quality dispositif falls within a tension between the aperture and the closure of the social. It runs by generating not only articulations and connections, but also disarticulations, disconnections and invisibilities. Three disarticulations are particularly noteworthy on account of their ideologizing effect. First and foremost is the one that unravels the principles underpinning its ideology, incorporating itself into the dispositif under the illusion of a particular technified and neutral universalism. In conjunction with the first, the second one disconnects texts and discourses from their socio-historical context, from their issuers, from their fields, again as a way to generate a universalizing, de-territorialized effect. Finally, the third one disarticulates statements from the fields and politics so as to place them in actors who are then called 'experts', thus generating a hierarchical and legitimizing effect of the principles, the discourses, the policies and the proposed practices, which puts a technical face on the ideological positions - ideology par excellence.

These disarticulations contribute to generating a 'universal common sense, they even make us forget that they have their origin in the complex and controversial realities of a particular historical society, tacitly constituted in make and measure of all things' (Bourdieu 2014: 207). The quality dispositif produces and contributes to producing 'systems of rules that impose how education can be talked about, who constitutes a serious spokesperson, and how desire, will, and cognition should be structured' (Popkewitz 1994: 241), a way of redefining the problems of education, schooling, and their relations with the social world, with a considerable re-disciplinary effect. In this way, as an organizer or regulator, quality generates 'a basis for symbolic struggles to producing and imposing the legitimate world view' (Bourdieu 1988: 136-137). However, the fact that 'quality' has been and is the sole articulating dispositif that condenses the debates, guidelines, recommendations, practices, examples, and discussions of educational reforms is no minor event, since being a phenomenon of the 'immigration of ideas', as Bourdieu explains (2014: 65), it is particularly forceful at imposing 'the updating of the reference horizon', which remains implicit. From this point of view, quality as a symbolic system has a peculiar epistemology. Within a rhetoric based on technical-instrumental rationality, quality contributes to generating an illusion of objectivity, neutrality and consensus in which the ethical-political dimension remains hidden and reduced to aspects of a procedural nature. Thus, beyond its potential aperture to disputes over its meaning, one of its main effects is its contribution to the processes of depoliticization of the social world in general and of education in particular. Quality dispositifs are not only a regulatory framework for discourses, policies and practices; they are above all a framework for the production of the truth about education. Quality is an articulator that connects the capitalist-liberal-neoliberal social ethos (Castro-Gómez 2015) to the field of education, thereby generating a peculiar type of discipline to guide, unify, and coordinate behaviours, actions and practices; configuring a grammar in which the conditions of possibility are demarcated within the dispositif itself. This works simultaneously as a possibility and as censorship by means of the structure that defines the network of elements that it 
condenses, and also acts as a spotlight, as a beacon that points out and sheds light on what must be said, what is correct and expected.

The theoretical approach that we have presented here integrates aperture and closure as two antagonistic aspects that are part of an inseparable whole. We thus accept that the social is not constituted analytically by isolated, clearly differentiable elements or positions that are articulated. The possibility of differentiating or fragmenting the social-cultural into isolatable elements with individualizable identities clearly disconnected from the social-cultural they are separated from is part of a contingent process entailing the construction of categories that explain and order the social world.

Received 10 June 2020

Accepted 7 September 2020

\section{References}

1. Amin, S. 1990. 'Colonialism and the Rise of Capitalism: A Comment', Science \& Society 54(1): 67-72.

2. Borón, A. 2000. Tras el Búho de Minerva. Mercado contra democracia en el capitalismo de fin de siglo. Buenos Aires: CLACSO.

3. Borón, A.; Cuéllar, Ó. 1983. 'Apuntes críticos sobre la concepción idealista de hegemonía, Revista Mexicana de Sociología 45(4): 1143-1177. DOI: 10.2307/3540333.

4. Bourdieu, P. 1988. Cosas dichas. Buenos Aires: Gedisa.

5. Bourdieu, P. 1989. 'Social Space and Symbolic Power', Sociological Theory 7(1): 14-25.

6. Bourdieu, P. 2014. Intelectuales, politica y poder. Buenos Aires: EUDEBA.

7. Castoriadis, C. 1997. 'Democracy as Procedure and Democracy as Regime', Constellations 4(1): 1-18. DOI: $10.1111 / 1467-8675.00032$.

8. Castro-Gómez, S. 2015. Revoluciones sin Sujeto. Slavoj Žižek y la crítica del historicismo posmoderno. Madrid: Akal.

9. Clarke, M. 2014. 'The Sublime Objects of Education Policy: Quality, Equity and Ideology', Discourse: Studies in the Cultural Politics of Education 35(4): 584-598. DOI: 10.1080/01596306.2013.871230.

10. Federici, S. 2004. Caliban and the Witch: Women, the Body and Primitive Accumulation. Brooklyn: Autonomedia.

11. Fernández-González, N.; Monarca, H. 2019. 'Política educativa e discursos sobre qualidade: usos e ressignificações no caso español', Revista Educación, Política y Sociedad 4(1): 55-83.

12. Foucault, M. 2004. The Birth of Biopolitics. Lecture at the College de France 1978-79. New York: Palgrave Macmillan.

13. Fraser, N.; Jaeggi, R. 2018. Capitalism: A Conversation in Critical Theory. Cambridge: Polity.

14. Gabay-Egozi, L. 2016. 'School Choice in a Stratified Geography: Class, Geography, Otherness, and Moral Boundaries', Journal of Education Policy 31(1): 1-27. DOI: 10.1080/02680939.2015.1047410.

15. Holloway, J.; Keddie, A. 2019. "Make Money, Get Money": How Two Autonomous Schools Have Commercialised Their Services', Discourse: Studies in the Cultural Politics of Education 40(6): 889-901. DOI: 10.1080/01596306.2018.1451305.

16. Kohan, N. 2013. Nuestro Marx. Madrid: La Oveja Roja.

17. Laclau, E.; Mouffe, C. 1985. Hegemony and Socialist Strategy: Towards a Radical Democratic Politics. London: Verso. DOI: 10.1177/072551368701600118.

18. Lander, E. (ed.). 2000. La colonialidad del saber: eurocentrismo y ciencias sociales. Perspectivas latinoamericanas. Buenos Aires: CLACSO.

19. Martínez, A. T. 2007. Pierre Bourdieu: razones y lecciones de una práctica sociológica: del estructuralismo genético a la sociología reflexiva. Buenos Aires: Ediciones Manantial.

20. Marx, K. 1990. Capital. London: Penguin Classics.

21. Monarca, H. (coord.). 2018. Calidad de la educación en Iberoamérica: Discursos, politicas y prácticas. Madrid: Dykinson.

22. Moschetti, M.; Verger, A. 2020. 'Opting for Private Education: Public Subsidy Programs and School Choice in Disadvantaged Contexts', Educational Policy 34(1): 65-90. DOI: 10.1177/0895904819881151.

23. Ozga, J. 2008. 'Governing Knowledge: Research Steering and Research Quality', European Education Research Journal 7(3): 261-272. DOI: 10.2304/eerj.2008.7.3.261. 
24. Popkewitz, T. 1994. Sociología política de las reformas educativas. Madrid: Morata.

25. Quijano, A. 2000. 'Coloniality of Power and Eurocentrism in Latin America', International Sociology 15(2): 215-232. DOI: 10.1177/0268580900015002005.

26. Wallerstein, I. 1983. Historical Capitalism with Capitalist Civilization. New York: Verso.

27. Žižek, S. 1989. The Sublime Object of Ideology. London: Verso.

HÉCTOR MONARCA, NOELIA FERNÁNDEZ GONZÁLEZ, ÁNGEL MÉNDEZ-NÚÑEZ

\title{
Socialinė tvarka, tiesos režimai ir simboliniai disputai: edukacinès politikos analizès apmatai
}

\begin{abstract}
Santrauka
Straipsnyje siūloma epistemologinę perspektyvą, kurioje galima analizuoti hegemonijos konstravimą edukacijos srityje kaip dabartinių debatų socialiniuose moksluose apie socialumo spragas ir pabaigą dali. Pagrindinè tezè teigia, kad, be tuose debatuose dominuojančios poststruktūralistinès tendencijos, reikètu peržiūrèti potencialius jos teorinių prielaidų padarinius socialiniam pasauliui, t. y. ne tik jo reprezentavimui, bet taip pat jo struktūroms, subjektams, objektams ir fenomenams apskritai. Remiantis pavyzdžiais, darbe analizuojami diskursai apie edukacijos kokybę, būdingas edukacinès politikos tendencijas nuo 1980-ųjų. Dar daugiau, šis diskursų tipas leido institucionalizuotoms galios struktūroms susieti tradicines „socialumo“ gamybos ir reprodukcijos formas su naujomis, kurios padeda konsoliduoti jo hegemoniją, pagerindamos našumą ir efektyvumą būdų, kuriais gaminamas ir kaupiamas kapitalas, ir taip juos legitimuoti. Išties, kaip orientyras, kokybė turejo ir vis dar tebeturi totalizuojantị poveikị hegemoniniam kapitalizmo prisitaikymui ir atgijimui, kuris prasidejjo 8-ojo dešimtmečio pabaigoje.
\end{abstract}

Raktažodžiai: socialiniai mokslai, politinè teorija, socialinè tvarka, tiesos režimai, simboliniai disputai, edukaciné politika 